Meta

Journal des traducteurs

Translators' Journal

\title{
Encoding Heteronormativity in the Target Culture: Slovenian Translations of The Merchant of Venice
}

\section{Vojko Gorjanc}

Volume 57, numéro 1, mars 2012

La CIUTI, chef de file pour la promotion de l'employabilité et de la recherche

CIUTI: Leader in Advocating Employability and Research

URI : https://id.erudit.org/iderudit/1012746ar

DOI : https://doi.org/10.7202/1012746ar

Aller au sommaire du numéro

Éditeur(s)

Les Presses de l’Université de Montréal

ISSN

0026-0452 (imprimé)

1492-1421 (numérique)

Découvrir la revue

Citer cet article

Gorjanc, V. (2012). Encoding Heteronormativity in the Target Culture: Slovenian Translations of The Merchant of Venice. Meta, 57(1), 145-158. https://doi.org/10.7202/1012746ar

\section{Résumé de l'article}

Le présent article traite de la façon dont les normes linguistiques et de traduction imposent une idéologie de l’hétéronormativité en Slovénie, comme en témoignent les dictionnaires. L'article vise à montrer comment les normes de traduction en matière d'homoérotisme se sont formées dans la traduction des textes classiques de la littérature slovène $\mathrm{du} \mathrm{xx}^{\mathrm{e}}$ siècle. Les normes de traduction, toujours inscrites dans une époque et un lieu donnés, sont formées par les traducteurs et autres agents de la traduction en rapport avec les conditions sociales et culturelles, les attentes et les adaptations des thématiques à ces dernières, les traductions soulignant le contraste entre les normes initiales et celles de la culture cible. De la même façon, la création de la norme linguistique de la langue standard résulte de l'adaptation continue des locuteurs à l'environnement social et culturel, conséquence de l'adaptation à l'idéal social en vigueur. Nous partons de l'hypothèse que les traductions ont contribué à la création d'un modèle hétéronormatif qui, à cause d'une production restreinte de nouvelles traductions des oeuvres classiques, continue à caractériser la communauté slovène d'aujourd'hui. L'article se conclut par une courte analyse de la représentation de l'homosexualité dans les traductions slovènes du Marchand de Venise de Shakespeare.
Ce document est protégé par la loi sur le droit d'auteur. L'utilisation des services d'Érudit (y compris la reproduction) est assujettie à sa politique d'utilisation que vous pouvez consulter en ligne.

https://apropos.erudit.org/fr/usagers/politique-dutilisation/ 


\title{
Encoding Heteronormativity in the Target Culture: Slovenian Translations of The Merchant of Venice
}

\author{
VOJKO GORJANC \\ University of Ljubljana, Ljubljana, Slovenia \\ vojko.gorjanc@ff.uni-lj.si
}

\section{RÉSUMÉ}

Le présent article traite de la façon dont les normes linguistiques et de traduction imposent une idéologie de l'hétéronormativité en Slovénie, comme en témoignent les dictionnaires. L'article vise à montrer comment les normes de traduction en matière d'homoérotisme se sont formées dans la traduction des textes classiques de la littérature slovène $\mathrm{du} x \mathrm{x}^{\mathrm{e}}$ siècle. Les normes de traduction, toujours inscrites dans une époque et un lieu donnés, sont formées par les traducteurs et autres agents de la traduction en rapport avec les conditions sociales et culturelles, les attentes et les adaptations des thématiques à ces dernières, les traductions soulignant le contraste entre les normes initiales et celles de la culture cible. De la même façon, la création de la norme linguistique de la langue standard résulte de l'adaptation continue des locuteurs à l'environnement social et culturel, conséquence de l'adaptation à l'idéal social en vigueur. Nous partons de l'hypothèse que les traductions ont contribué à la création d'un modèle hétéronormatif qui, à cause d'une production restreinte de nouvelles traductions des œuvres classiques, continue à caractériser la communauté slovène d'aujourd'hui. L'article se conclut par une courte analyse de la représentation de l'homosexualité dans les traductions slovènes du Marchand de Venise de Shakespeare.

\begin{abstract}
This article discusses how linguistic and translation norms, as evident in dictionaries, enforce the ideology of heteronormativity in Slovenia. The aim of this paper is to show how translation norms concerning homoeroticism were shaped in the translation of classical literature in Slovenia in the twentieth century. Translation norms are shaped in a certain period of time and in a certain environment among translators and others involved in translation according to social and cultural circumstances, expectations, and adaptations of topics to these expectations, in which the translation contrasts the initial norms with the norms of the target culture. At the same time, the linguistic norms of the standard language are created as a result of speakers' continuous adaptation to a social and cultural environment, as a result of adapting to the current social ideal. It is assumed that translations contributed to creating a model of heteronormativity, which continues to characterize the Slovenian community today because of the limited number of new translations of classical works of literature. The paper concludes with a brief analysis of evidence of homosexuality in Slovenian translations of Shakespeare's The Merchant of Venice.
\end{abstract}

\section{MOTS-CLÉS/KEYWORDS}

normes de traduction, normes linguistiques, littérature classique, hétéronormativité, Slovénie translation norms, linguistic norms, classical literature, heteronormativity, Slovenia 


\section{Introduction}

Linguistic and cultural communities with a relatively small number of speakers are often characterized by intense intercultural contacts through translation. This is also true in the case of Slovenia: the specific feature of Slovenian linguistic and cultural space since the very beginning of the standardization of Slovenian has been translation (Pokorn and Vogrinc Javoršek 2007: 4-5). This has been part of all the key stages of the process of creating standard Slovenian since the mid-sixteenth century. The first Slovenian manuscripts were created in the tenth century ${ }^{1}$ based on Latin and German sources (Glavan 2007: 9), and translation clearly played a role in the standardization process for Slovenian; for example, in Jurij Dalmatin's 1584 translation of the Bible. Translation significantly marked the standardization of Slovenian as well as its codification in the first grammar of Slovenian from the same year by Adam Bohorič. This grammar was written in Latin and was based on Latin grammars, but it codifies standard Slovenian as shaped in Protestant works (both original texts and translations) from the second half of the sixteenth century. Because Slovenian cultural space was in constant contact with Germanic, Romance, Slavic, and Hungarian space, it was also distinctly marked by intercultural exchange through translation activity, and translation actively shaped the development of Slovenian and its entire literary production (Pokorn and Vogrinc Javoršek 2007: 5).

In the development of standard Slovenian, translation has contributed above all to broadening the scope of use of Slovenian and to the introduction of new genres. Literary translation, which has often had the role of a linguistic challenge in the Slovenian community in the sense of proving that Slovenian can express the same things as "bigger" and culturally "stronger" languages, has played an important role in the development of the language (Stanovnik 2005) and has consequently always presented a significant part of literary production. This is still true today (Pokorn 2008: 5).

Translation norms are shaped in a certain period of time and in a certain environment among translators and others involved in translation according to social and cultural circumstances, expectations, and adaptations of the topics to these expectations, whereby the translation is faced with the initial norms and with the norms of the target culture (Toury 1995: 56). Translation has established an intercultural dialogue between the programmatic and ideological postulates of the European space and the Slovenian cultural community, in which it actively contextualized the programmatic and ideological premises of the European space into the authorial and linguistic world of Slovenian literary production (Stanovnik 2005: 13). In this manner, European cultural values became part of the general values and ideas of the Slovenian cultural community, reshaped in line with the cultural values of Slovenian society. At the same time, texts were translated according to the linguistic norms of the standard language, also created as a result of a continuous adaptation to the Slovenian social and cultural environment, as a result of adapting to the current social ideal, as is the usually case in the language standardization processes (Béjoint 2000).

Consequently, any description of a language is ideologically marked in one way or another. The linguistic norms are furthermore characterized by linguistic intervention from the position of power to regulate the language adopted above all by linguists, who, at a given moment, take on the role of interpreting linguistic phenomena and 
judging them. Because the description of Slovenian lexical and grammatical norms is largely based on textual data - above all on literary texts, including the entire canon of translations of classical works of literature - many linguistic descriptions of Slovenian are still based on the translation norms that emerged from the translations of classical literature. In fact, Slovenian translators of literary texts took an active part in discussing the Slovenian linguistic norm, both lexical and grammatical, in that period (Thomas 1997; Korošec 2002). The translators thus shaped standard Slovenian in an important way with both their translation activity and their active involvement in the standardization process, publicly discussing language standardization, writing scholarly articles, and also by being members of editorial boards of several normative language reference books.

\section{Aim of the study and hypothesis}

This article shows how translation norms and translation attitudes concerning homoeroticism were shaped in the translation of classical literature in Slovenia in the twentieth century. The study also focuses on how translators' views on homosexuality and homoeroticism influenced the linguistic norms of standard Slovenian, as is evident in dictionaries, and thus established the basis for the standardization of heteronormativity - a concept within Western societies that institutionalize the ideology of the universality of heterosexuality and, through a series of cultural patterns, social norms, and legal norms, establish a hegemony of heterosexuality (Yep, Lovaas et al. 2003; Lovaas and Jenkins 2007). This therefore involves the concept of Western society, in which "[h]eteronormativity defines not only a normative sexual practice but also a normal way of life” (Jackson 2006: 107).

It is assumed that translations and translators contributed to the creation of a model of heteronormativity, which still continues to characterize the Slovenian community because of the limited number of new translations of classical works of literature. This model corresponded to the prevailing attitude towards homosexuality in Slovenian society, which was largely shaped by Roman Catholic morality. After the Second World War, this kind of attitude was also very much in agreement with socialist ethical and moral standards. In Slovenia at the beginning of the 1990s, space was intentionally created for translations of LGBTQ texts through the designing of a number of book series for LGBTQ literature in translation; gay activists actively engaged in this process as authors, translators, and editors (Bibič 2010). In addition, with more recent translators there have been substantial changes in translations, also including issues of homoeroticism. The basic reason it is presumed that literature in translation is still contributing to preserving the model of heteronormativity is the translation of literary classics, which are part of required reading, in part even in elementary school and even more so in secondary school. Because there are few new translations of the literary classics, the school population is faced with an ideological model of heteronormativity that is reproduced through the school system. Here it is not unimportant that such texts, which occupy an important part of the school curriculum, cannot be used in modern teaching practice for identification with characters and situations from the perspective of the complexity of "relationships among the various ways in which sexualities are organized and identified" (Sumara and Davis 1999: 203). 
It is also hypothesized that, because of the influence of translated literature and the explicit viewpoints of the translators, which formed the basis for the creation of standard Slovenian, this will also be noticeable in linguistic descriptions, especially lexicographic ones. Detailed analyses of the description of Slovenian in dictionaries reveal the social values reflecting the current social ideal, which is largely formed by translation.

Such views and translation solutions immediately become clear when an unaltered literary translation from the beginning of the twentieth century is used in a new situation; for example, a film adaptation of a literary work explicitly thematizes homoeroticism, but the subtitles in which such a translation has been used do not allow for an open interpretation, let alone follow the explicitness of homoeroticism in the film adaptation, as was the case with the film The Merchant of Venice (2004). ${ }^{2}$ The interpretation of the original text given in the film thus tells a completely different story from that rendered in the Slovenian subtitles.

\section{Methodology}

To begin with, I examine the forewords and prefaces to the translations and the commentaries by the translators on their translation decisions in translations of classical Greek and Renaissance works published in the first half of the twentieth century and the introduction to the translation of Plato's Symposium written by the translator Anton Sovrè. Sovrè also took an active part in the normative regulation of the Slovenian linguistic standard. These texts are used to try to determine the attitudes toward translating erotic and homoerotic content. This is followed by a qualitative analysis of the translations of William Shakespeare's The Merchant of Venice by Oton Župančič from 1905 and 1921. I analyze the translation and the foreword published in 1972 in the Kondor book series, which was intended for students and had a defining role in interpreting Shakespeare's work in Slovenia. Parallel to this, I analyze the lexical elements connected with homosexuality and homoeroticism in the Slovar slovenskega knjižnega jezika (Standard Slovenian Dictionary, 1970-1991) and Slovar slovenskega pravopisa (Dictionary of the Slovenian Normative Guide, 2001), and the written corpus of texts at the Slovenian Academy of Sciences and Arts that was the basis for the Standard Slovenian Dictionary. This analysis is used to show how translated literature affected the lexical norm of Slovenian. Special attention is paid to how translation decisions and their transfer into the dictionary description and consequently into the Slovenian cultural community encoded heteronormativity. For observing the current situation of the norm of standard Slovenian, the 621-millionitem FidaPLUS ${ }^{3}$ reference corpus of Slovenian is used.

The analysis then focuses on the Slovenian translation of Shakespeare's The Merchant of Venice by Oton Župančič from 1905. The same translator translated other plays written by Shakespeare, and his translations, in a sense, encoded the reading of Shakespeare in Slovenian. It is assumed that analysis of this translation, which varies in terms of adequacy (in the sense of following the source text) and acceptability (in the sense of adapting it to the target culture), reveals the poetics and ideology of the period in those parts of the text that are open to interpretation. The adaptation to the target culture is particularly obvious in the analysis of the Slovenian subtitles of the 2004 film The Merchant of Venice if one considers the (homo)erotic 
parts of the text. The Slovenian subtitles of the film are based on Župančičs 1921 translation, which is a slightly adjusted version of his 1905 translation, whereas the introductory part, which is new in the film, is translated in line with Župančič's poetics and his translation decisions.

\section{The code of behavior and ideology of heteronormativity}

A translation is contextualized in the existing (literary) system of an individual cultural environment. This section addresses how translators enter the discourse of heteronormativity through their translation activity and translated texts and how they establish, support, or deconstruct the cultural pattern of heterosexual hegemony. The analysis is based on literary systems theory (Lefevere 1982). It focuses less on the extent to which the literary system is controlled by regulatory bodies and more on how the literary system "possesses a kind of code of behaviour" (Lefevere 1982: 6). Slovenian has a small number of speakers and, from the perspective of poetics and the code of behavior, it is also marked to a lesser degree by competition among poetics for domination, and so a correspondingly greater role is played by individuals whose code of behavior becomes the ruling norm. Also of interest is how limitations in the system function in the Slovenian space as posed by "natural language in which a work of literature is written, both the formal side of the language [...] and its pragmatic side, the way in which language reflects culture" (Lefevere 1982: 6).

\subsection{Translator(s)' attitudes towards homosexuality}

An analysis of the forewords and prefaces to the translations of classical Greek and Renaissance works and the commentaries of the translators on their translation decisions regarding questions of homosexuality reveals two approaches: a nullifying approach, in which homoeroticism is not mentioned, or the approach of explicitly revealing one's viewpoint, which is always extremely negative. However, this concerns only a single translator, Anton Sovrè, who was one of the most influential translators of classical Greek literature into Slovenian. During the two world wars he was also considered the greatest expert on Antiquity in Slovenia, and was entrusted with writing a monograph on the ancient Greeks, mainly due to his experience in translation because he had already translated several poetic and philosophical texts (Gantar 2002). In his monograph on the ancient Greeks Sovrè explicitly expresses his attitude towards homoeroticism, which permeates his writing about it in translating Greek classical literature:

Cohabitation with members of the same sex increased pederast $y^{4}$ among the Spartans, which was something the Greeks had in them in general. It is a disgusting matter for a normal person, no matter how hard the solicited or unsolicited moralists try to ethically embellish it. [...] Pederasty is one of the few detestable things that repel one from the Greeks, especially when one sees that even men such as Sophocles and Socrates did not lack this filthy predisposition. ${ }^{5}$ (Sovrè 1939: 113-114)

This viewpoint is important because the monograph was published as a reprint in 2010 and is practically the only comprehensive overview of ancient Greece in Slovenian. In terms of translated works, the stance of the same translator towards 
homoeroticism significantly marked the preface to the translation of Plato's Symposium (Sovrè 1960).

Anton Sovrè articulates his views on every segment of ancient literature and refers to translations of Greek epic and lyric poetry, as well as drama. By resorting to a discourse marked by expressive language, as is already clear from the quotation above, he establishes a very negative attitude towards homoeroticism in Greek classical literature as well as in general:

If we take a closer look at homoeroticism in Greek literature, we see that the beginnings of pederasty go back to prehistoric times, indeed, to the twilight of mythology. (Sovrè 1960: 10-11)

[In] lyric poetry homoeroticism played an important role. [...] Almost all lyric poets were sexually inverted. [...] Greek lyric poetry certainly has traits of eternal beauty, which, unfortunately, is so permeated with homoerotic outbursts that one has the feeling of holding a beautiful flower whose leaves have been stained by the slime trail of a snail. (Sovrè 1960: 12-13)

In drama, homoerotic motifs were so common that some older critics considered tragedy a breeding ground for pederasty, which had an outright dominant role in Greek comedy. (Sovrè 1960: 14)

All or almost all cultural creations of the Greeks [...] are based on the ethical assessment of manhood; that is why they are often not entirely pleasant to a modern person. (Sovrè 1960: 22)

Pederasty was considered ethically sound to a Greek, much as it is for a Negro to eat his father, who is happy to find his grave in his son's stomach. (Sovrè 1960: 30)

In contrast to such explicitly articulated attitudes towards homoeroticism, some translators tend to avoid the issue completely, which can be understood as a type of censorship. Some authors consider the suppression of texts or facts about the author, or adapting the translation, to be a form of external censorship (Mozetič 1997: 254); the suppression of homoeroticism in commentaries and prefaces could also be considered in this context. Apart from the explicit viewpoints of a single translator mentioned above, this topic enters the discussion only exceptionally; for example, in the foreword to the translation of Shakespeare's The Merchant of Venice as a minor note on the fact that Antonio's sacrifice for Bassanio is "essentially an erotic relation, which is no stranger to death" (Zupančič 1972: 97).

\subsection{Linguistic norms based on translation ideologies}

Methodological approaches in the process of language standardization vary, but in principal most are based on language use data (Nebeská 1996). In Slovenia, dictionary definitions and, to a somewhat lesser extent, grammatical definitions, are based on data derived from real-life communication. Due to the importance of translation in shaping the Slovenian cultural space and in establishing norms of standard Slovenian in the past as well as today, translated literature, including commentaries and forewords, is commonly included in reference language resources. The basis for the creation of the primary dictionary reference, the Standard Slovenian Dictionary, thus contains almost all translations of classical literature published in the twentieth century (Seznam 1965). 
Language reference books, especially dictionaries, have an important social role - in society they are perceived not only as the lexicon of a language, but also as a cultural treasury or even a treasury of national knowledge (Béjoint 2000: 121). However, because we live in a world of both positive and negative prejudices, which are codified in a language, these prejudices become part of the lexicographic discourse. Even if they disappear from society, they remain fossilized in expressions that we are frequently not even aware of. It is perfectly clear that prejudices in a language community, most often connected with stereotypes, change over time (Schutz 2002: $637,638)$, which is not necessarily reflected in changes in the lexicographic discourse. Essentially, every dictionary is ideological in one way or another, which is reflected in its macrostructure and microstructure in the choice of entries, through definitions, and especially through the selection of usage examples. Dictionaries reflect power relations in society (Goddard and Patterson 2000: 73-74), cultural and social values, and they communicate cultural and social norms through descriptions of language norms.

In analyzing the language resources that formed the basis for dictionary definitions in the Standard Slovenian Dictionary and the Dictionary of the Slovenian Normative Guide ${ }^{6}$ and analyzing dictionary definitions, the goal is to determine to what extent the viewpoints held by translators and their translation solutions influenced dictionary definitions. Another goal is to determine whether dictionary definitions thus created codify heteronormativity in the Slovenian cultural environment, as hypothesized. The analysis focuses on two lexical groups: pederast (pederast), pederastija (pederasty), pederastičen (pederastic) and homoseksualec (homosexual [noun]), homoseksualnost (homosexuality), homoseksualen (homosexual [adjective]).

A detailed inspection of the data on the use of the first lexical group confirms the predictions that the lexicographers working on the dictionary had at their disposal data from medicine and journalism, but above all original Slovenian literature and translated texts and forewords to translations into Slovenian, the source of the latter frequently being Anton Sovrè. For the lexicographers, the data from original literature and translations for the lexical elements pederast (pederast) and pederastija (pederasty) raised the question as to the meaning of the two lexemes. The meaning used in non-literary texts for pederast "a man that has a sexual inclination towards children and youth" and pederastija "sexual inclination of a man towards children and youth" was supplemented with a definition based on literary texts, which was synonymous with the meanings of homoseksualec (homosexual) and homoseksualnost (homosexuality). The lexicographers (as is clear from the language resource used for the Standard Slovenian Dictionary) even requested an opinion from the Ljubljana Psychiatric Hospital and on October 6, $1975^{7}$ received a detailed clarification that using the term pederast (pederast) for a homosexual person is not correct. It was also explained that the correct terms to be used are homoseksualec (homosexual) and homoseksualnost (homosexuality). In spite of this, the Standard Slovenian Dictionary under the dictionary entry pederast (pederast) also includes the meaning "homosexual person" with a label concerning usage limitation, which states that the term is used in elevated literary language.

In contrast to the meaning defined in the Standard Slovenian Dictionary, which contains a label on usage limitation, the Dictionary of the Slovenian Normative Guide, published in 2001, provides a far worse definition because it does not indicate any 
usage limitations, or explicate an adequate meaning. Although the entry peder ( $f a g)$ contains the label low, the entries pederast (pederast), pederastija (pederasty) and pederastičen (pederastic) have no such label despite the fact that in the corpus they are used only with a derogatory meaning. Based on current data from the FidaPLUS contemporary corpus of Slovenian texts, one would expect in a dictionary explication that this was a term used for homosexuals and homosexuality in the nineteenth century, or a reference to the negative connotation it has today. A very sensitive place in the dictionary definition thus establishes a lexicographic discourse, which, based on its seemingly neutral relation to marked discourse in real-life communication in the Slovenian discourse space, enables the use of lexical elements with a negative connotation in a quasi-neutral discourse. The argument for its "neutrality" is often based precisely on the definition in the dictionary.

It is these sorts of solutions in combination with other dictionary definitions that make it possible to equate two entirely separate meanings and terms, which is demonstrated in the use of the dictionary definition in a current newspaper text. Such dictionary definitions provide the argument for the perpetuation of heteronormativity on the supposition of the deviancy of homosexual practices:

All circumstances associated with the fate of these two cities [Sodom and Gomorrah] are described in the Bible, near the beginning. If you had ever read it, you would have realized that the main "weakness" of the inhabitants was homosexuality and how the women and young people dressed or behaved. One could say, if I imitate your way of twisting the words, that it was exactly this kind of "sexual practice for reinforcing their ties and forming the community" that brought them the punishment, which was so thorough and final that even nonbelievers refer to it thousands of years later. By the way, the less frequently used word sodomite also derives from the name Sodom. Think about it; someone wrote a "very uncivilized" definition in the Standard Slovenian Dictionary that the meaning of this word is a homosexual, a sexual pervert. (Novak $2004)^{8}$

The existing dictionary solutions, combined with the undisputed authority the Standard Slovenian Dictionary enjoys in Slovenia, are also used for the stigmatization of social groups already stigmatized and provide an argument for the spread of intolerance (Gorjanc 2005: 200).

Definitions and usage examples are two elements of a dictionary in which ideology can be expressed in two very different ways. When defining a word, lexicographers are much more limited with the language used in definitions, which decreases the potential for ideology. When ideology is present, it is usually explicit and mostly reflects the general political, ideological and moral values. On the other hand, the selection of usage examples gives more freedom. The primary function of usage examples is to illustrate syntactic features or collocational restrictions, or to provide additional semantic information. The selection of usage examples often reflects social reality as perceived by the lexicographer. In this way, a preference that the lexicographer cannot realize in the definition is established. This is why the analysis of usage examples is one of the most interesting research topics concerning ideology in dictionary definitions (Béjoint 2000: 135).

The Standard Slovenian Dictionary contains appropriate definitions for the second group analyzed: homoseksualec (homosexual [noun]), homoseksualen (homosexual [adjective]) and homoseksualnost (homosexuality). This is not the case, however, when 
the usage examples in the lexicographic discourse are analyzed: "he strayed from the right path into the company of homosexuals and onanists" (s.v. onanist); "exhibitionism, fetishism, homosexuality, and other perversions" (s.v. perverzija (perversion)); "homosexuals, exhibitionists and other sexual perverts" (s.v. perverznež (pervert)); "homosexuality, exhibitionism and other perversions" (s.v. perverzija (perversion)); "homosexuals and other deviants / sexual deviants" (s.v. sprevrženec (deviant)). In spite of its appropriate definitions, the Standard Slovenian Dictionary is clearly ideological in its choice of usage examples. In this part, the dictionary does not rely as much on literary works as in the analysis of the previous group of lexical elements, and it derives very little linguistic information from translated texts. However, linguistic data reveal that lexicographers had neutral textual contexts at their disposal, but opted for ones with negative connotations.

By analyzing the chosen lexical elements, it has been shown that the inclusion of translated texts and the viewpoints of the translators into the language source that forms the basis for the description of the linguistic norm can significantly help shape the linguistic norm and, consequently, codify general cultural and social norms as a sort of social ideal. However, as lexicographic discourse re-enters public discourse, due to the importance of the dictionary argument, it preserves the codified social norms. For lexical elements connected to homosexuality, lexicographic solutions in standard Slovenian dictionaries not only institutionalize the universality of heterosexuality, but also set heterosexuality as the norm, with homosexuality being presented not only as a deviation from the norm but as a deviancy.

\section{3. (Non-)evolution of translation norms}

In the final stage, I explore how translation norms connected with issues of homoeroticism fit into the context of social norms in Slovenia based on the translation of The Merchant of Venice by William Shakespeare. As is the case with social norms, translation norms regulate the actions of individual agents in society. Translators, as one type of such agents, are also part of this social process (Toury 1995: 54-55). The evolution of social norms also brings about changes in the behavior of all agents, and so translation norms also become part of the process of social evolution.

\subsubsection{Homoeroticism in Slovenian (literary) tradition}

Historically, translation norms were closely connected with changes in the literary system (Lefevere 1982: 5-6), but this is also part of the generally accepted norms in a certain environment at a certain period of time (Toury 1995: 53). Homoeroticism enters Slovenian original literature in the first half of the twentieth century, but the topic becomes more prominent only after the Second World War. Generally, however, homoeroticism and homosexuality are not very frequent motifs in original Slovenian literature (Mozetič 2001: 373; Zupan Sosič 2005: 6). When the topic enters Slovenian literary production, it is usually limited to the male sphere, which functions as an excuse, explanation, apology, and so on, be it in school, prison, the military, a POW camp, or a monastery (Mozetič 2001: 376). The transition of homoeroticism in the Slovenian modern novel from stereotyping to the normalization of sexual identity is slow and follows the pattern of heterosexuality (Zupan Sosič 2005: 5). 
The Slovenian literary tradition of homoeroticism and homosexuality is thus in sync with general social norms as they are represented in the Slovenian public:

Stereotyping, medicalization, sexualization, secretiveness, and also normalization [...] represent the pivotal points in media representation in which the boundaries of political correctness in media reporting are tested or even exceeded. It is these points that preserve and perpetuate the negativity in the attitude towards homosexuality, although they generally wish to change such viewpoints. Homosexuality still causes insecurity and uneasiness, fear, and anxiety. This results in clear references to this topic in public and popular discourse being suppressed and subdued, hidden in stereotype images that are easily placed into the reader's or viewer's notions of homosexuality and are, therefore, not disturbing. (Kuhar 2003: 92-93)

Even though this does not necessarily only involve a characteristic of Slovenian cultural space, awareness of how Slovenian society operates, as summarized in the analysis above of the media representation of homosexuality, is important for understanding the dialogue of literary translation with existing social reality.

\subsubsection{The translation of The Merchant of Venice and its role in codifying heteronormativity}

The translation of The Merchant of Venice is placed in the social context mentioned above and its role is investigated in the construction or deconstruction of heteronormativity in Slovenia.

The first translation of the play into Slovenian was published in 1905 by the Slovenian poet and translator Oton Župančič (Shakespeare 1600/1905). With some slight modifications, the translation was published again in 1921 (Shakespeare 1600/1921). The translation was later published in selected works (Shakespeare 1600/1948) and then in collected works (Shakespeare 1600/1971), in which some missing verses and stage comments were added. All the editions retain the commentaries of the translator and later editor of the collected works, Matej Bor (pen name of Vladimir Pavšič). In the postwar editions, the texts were adapted to the new normative rules (Moder 1972: 101). One of the most widespread editions, based on the edition from 1971, was published a year later in the Kondor book series, intended for students (Shakespeare 1600/1972). The most recent translation into Slovenian is from 2011 by the translator, poet, and playwright Milan Jesih. It was published in the program of the play when it was staged at Drama (the Slovenian National Theatre) in the 2010/2011 season (Kranjc 2011).

The motivation for this discussion is the use of the translation by Oton Župančič from the beginning of the twentieth century in the subtitles of the film The Merchant of Venice, which was released in Slovenian cinemas in 2005.

Comparing the translation with the original opens the translation to interpretation in accordance with translation norms and socially acceptable behavior of the time, which is also made explicitly clear in the commentaries in the preface. Namely, the relationship between Antonio and Bassanio is interpreted as "a friend's sacrifice" (Kelemina 1921: 17-18) or "a sacrifice made for a friend and friendship" in later editions (Zupančič 1972: 97), which is made explicit in the translation of Antonio's speech to Bassanio: 
English

Tell her the process of Antonio's end, Say how I loved you, speak me fair in death, And when the tale is told, bid her be judge Whether Bassanio had not once a love.

\section{Slovenian}

Žêni me svoji blagi priporoči: povej, kako Antonio je končal, kako sem ljubil te; lepo spominjaj se me po smrti; potlej naj presodi, je li Bassanio imel prijatelja.

(Shakespeare 1600, Act 4, Scene 1; translated by Župančič, in: Shakespeare 1600/1921, p. 120-1219)

The opening "I loved you" is open to interpretation and remains so in the Slovenian translation sem ljubil te (I loved you); the ending "had not one a love," however, is translated as imel prijatelja (had a friend). ${ }^{10}$ The use of such a translation in the subtitles is in complete contrast to the story in the film, which explicates the homoerotic relationship. The decision to use an unmodified translation in the subtitles can be understood from an economic point of view, but the Slovenian distributor should have been familiar with the content at least to the extent of doubting its appropriateness. ${ }^{11}$ The sexuality of male characters and the question of homosexuality in Shakespeare's works have been the topic of several studies in the past twenty years (Smith 1994; Goldberg 1994; Mahood 2003: 54). Even if these studies were unknown, the film interpretation itself is clear enough and there was plenty of media coverage of the homoerotic interpretation of the film. ${ }^{12}$ The same subtitles were also preserved in the DVD edition, although the presentation of the film in the blurb starts with the following: "A melancholic Antonio is in love with the young Bassanio."

At the time of the publication of the first translation of The Merchant of Venice into Slovenian, homosexuality was deemed socially unacceptable behavior. Parts of the text that were open to interpretation were therefore translated in line with socially acceptable behavior, which meant that a potentially homoerotic relationship was interpreted and translated as socially acceptable friendship, which clearly codified heteronormativity. Because a long time had passed before a new translation was published, and the book version used by students is a reprint of an only slightly altered translation from 1921, the heteronormativity of the text has been taken for granted and was only revealed when the same translation was used in the subtitles of a movie that thematizes homoeroticism. With the last staging of The Merchant of Venice at the Slovenian National Theatre in Ljubljana, Slovenians received a new translation that breaks with the tradition of heteronormativity because of the changes of the social norms, an increasingly present discussion of homoeroticism in Renaissance texts, and the specific norms in the Slovenian cultural environment. However, because it is a text limited to the medium of a play program and does not normally reach the segment of society that has most contact with this text - namely, students - heteronormativity actually remains the norm and an open interpretation of it remains on the margins of translated literature.

\section{Conclusion}

The article has from various angles explored translation and linguistic norms in the Slovenian-speaking community, which is marked by intense intercultural contact, also through translation activity. Translation norms are shaped in a certain period and in a certain environment between translators and others involved in translation 
according to existing social and cultural norms, and the same is true of linguistic norms. In communities that are shaped by intense intercultural contact through translation, those involved in translation also have a significant role in shaping linguistic norms, both directly with the active role of standardizing the language, as well as through their translations, which become part of the process of language standardization. Social changes bring about changes in translation practice and consequently in translation norms. The same is true of linguistic norms, which can also be observed though time. It becomes problematic when influential linguistic descriptions and translations that were formed in a different environment and in a different period of time give the impression of being accurate in the present. However, in fact they codify the values of a different period; they codify what was considered tolerable in a different period and what was acceptable in a different period. It is the same with codifying heteronormativity. Through their translation activity and translated texts, translators also enter the discourse on heteronormativity and establish, support, or reconstruct the cultural pattern of heterosexual hegemony. The absence of new translations of classical works with homoerotic content combined with linguistic descriptions that were formed largely on the basis of original texts and translations, which are known to have been formed in times of intolerance and rejection of homosexuality, institutionalize the ideology of heterosexual universality in Slovenia.

\section{ACKNOWLEDGMENTS}

I would like to thank Andreja Žele from the ZRC SAZU Fran Ramovš Institute of the Slovenian Language, who enabled me to access the full list of works included in the reference language resource used for the Standard Slovenian Dictionary (1970-1991), as well as the language resource itself.

\section{NOTES}

1. The text of the Freising Manuscripts with an English Introduction is available at the Scholarly Digital Editions of Slovenian Literature website. Visited on 20 December 2011, <http://nl.ijs.si/e-zrc/ bs/index-en.html>.

2. The Merchant of Venice (2004): Directed by Michael RADForD. Hollywood: Sony Pictures Classics, 2004.

3. FidaPLUS - corpus slovenskega jezika. Visited on 24 June 2011, <http://www.fidaplus.net $>$.

4. Anton Sovrè explains this term as follows: "The Greek term for male homoeroticism was paiderastia [...]. The word pederasty bore no pejorative connotation in Greek as is the case today [...]. Apart from the word pederasty, the Greeks also used the term paidofilia in the same sense. In Slovenian, I differentiate between the two: I use pederasty in the sense of crude physicality and paidofilia in the sense of ethically pure spiritual love" (Sovrè 1960: 7-8).

5. Quotations in the article are translated by Martin Grad.

6. In 1945, the language resource started as an index card collection, which now contains over 3.4 million index cards. ZRCSAZU, visited on 24 June 2011, <http://isifr.zrc-sazu.si/index.php?q=sl/ node/30>.

7. Here I leave aside the discussion of the appropriateness of the institution to which the question was directed. Namely, the very selection of the institution for consultation on the issue suggests that homosexuality is classified as an illness.

8. NovaK, France (22 May 2004): Letter to the editor, in reply to an article on homosexual marriages, Ko si fant in fant obljubita zvestobo. PP 29, Delo, Sobotna priloga, 39.

9. Shakespeare, William (1600/1955): The Merchant of Venice. The Arden Shakespeare, second series. Complete Moby Shakespeare. Visited on 31 March 2012, <http://shakespeare.mit.edu/merchant/ index.html>. 
10. It is reasonable to assume that this was not a coincidence because Oton Župančič was very faithful to the original and even commented on changes made to set phrases. In one of the commentaries he noted the change from "sleeps by day / more than the wild-cat" to spi več nego polh (sleeps more than a dormouse) (Shakespeare 1600/1905: 118).

11. A similarly inappropriate translation appears in the dramatic conflict between Antonio and Shylock, where the use of Župančič's lexeme žid (Jew), which has a negative connotation in most contexts in Slovenian, and the lexeme jud, which is used in neutral contexts in the corpus of modern Slovenian texts, blurs the dramatic conflict between the Jewish and the Christian community.

12. For example, the interview with Joseph Fiennes on BBC, in which he defines the relationship between Antonio and Bassanio as "absolute love between one man and another." AppleBAum, Stephen (Last updated: December 2004): Movies - Joseph Fiennes - The Merchant of Venice (interview). BBC. Visited on 24 June 2011, <http://www.bbc.co.uk/films/2004/11/30/joseph_fiennes_ the_merchant_of_venice_interview.shtml $>$.

\section{REFERENCES}

BÉJoInt, Henri (2000): Modern Lexicography. An Introduction. Oxford: Oxford University Press. BıвIČ, Špela (2010): Prevajanje kot družbena dejavnost: uredniška politika založbe ŠKUC pri prevajanju LGBTQ besedil. Master's thesis, unpublished. Ljubljana: Univerza v Ljubljani, Filozofska fakulteta.

Gantar, Kajetan (2002): Anton Sovrè in njegova monografija o Starih Grkih. In: Anton Sovrè, ed. Stari Grki. Reprint from 1939. Ljubljana: Slovenska matica.

Glavan, Mihael (2007): The First Written Texts in Slovene. In: Nike K. PokorN and Urša VOGRINC JAVORŠEK, eds. Vta Slouenski jesig preobernen. Vloga prevoda v razvoju slovenskega jezike in književnosti [The Role of Translation in the Development of Slovene Language and Literature]. Ljubljana: Univerza v Ljubljani, Filozofska fakultete, Oddelek za prevajalstvo, 7-9.

Goddard, Angela and Patterson, Lindsey Meân (2000): Language and Gender. London: Routledge.

GoldBerg, Jonathan, ed. (1994): Queering the Renaissance. Durham: Duke University Press.

GORJANC, Vojko (2005): Neposredno in posredno žaljiv govor v jezikovnih priročnikih: diskurz slovarjev slovenskega jezika. Družboslovne razprave. 21(48):197-209.

JaCkson, Stevi (2006): Gender, Sexuality and Heterosexuality: The Complexity (and Limits) of Heteronormativity. Feminist Theory. 7(1):105-121.

Kelemina, Jakob (1921): Uvod. In: William Shakespeare. Beneški trgovec. [The Merchant of Venice] (Translated by Oton ŽupančIĆ). Ljubljana: Nova založba, 3-26.

KorošEc, Tomo (2002): Sovretovi nepravi relativniki. In: Marko JesenšEK, ed. Nacionalno, regionalno, provincialno, Zbornik Slavističnega društva Slovenije 13. Ljubljana: Slavistično društvo Slovenije, 42-51.

KranjC, Mojca (2011): William Shakespeare, Beneški trgovec. Gledališki list SNG Drama Ljubljana. Ljubljana: SNG Drama.

KuHAR, Roman (2003): Medijske podobe homoseksualnosti: Analiza slovenskih tiskanih medijev od 1970 do 2000. Ljubljana: Mirovni inštitut.

Lefevere, André (1982): Mother Courage's Cucumbers: Text, System and Refraction in a Theory of Literature. Modern Language Studies. 12(4):3-20.

LovaAs, Karen E. and Jenkins, Marcielee M., eds. (2007): Sexualities and Communication in Everyday Life: A Reader. London: Sage Publications.

MaHood, Molly Maureen (2003): Introduction. In: Molly Maureen MAHOoD, ed. The Merchant of Venice. Cambridge: Cambridge University Press, 1-65.

Moder, Janko (1972): Opombe. In: William Shakespeare. Beneški trgovec. Ljubljana: Mladinska knjiga, 101-110.

Mozetič, Brane (1997): Literatura na margini? Časopis za kritiko znanosti. 25(185):253-264.

Mozetič, Brane (2001): Slovenski roman in lik homoseksualca. Časopis za kritiko znanosti. 29(201-203):373-381. 
Nebeská, Iva (1996): Jazyk, norma, spisovnost. Prague: Univerzita Karlova.

PокоRn, Nike K. (2008): Translation and TS Research in a Culture Using a Language of Limited

Diffusion: The Case of Slovenia. JoSTrans: The Journal of Specialised Translation. 5(10):2-9.

Pokorn, Nike K. and Vogrinc JaVoršEk, Urša, eds. (2007): Vta Slouenski jesig preobernen.

Vloga prevoda $v$ razvoju slovenskega jezike in književnosti [The Role of Translation in the Development of Slovene Language and Literature]. Ljubljana: Univerza v Ljubljani, Filozofska fakultete, Oddelek za prevajalstvo.

Schutz, Rik (2002): Indirect Offensive Language in Dictionaries. In: Anna BraAsCH and Claus Povlsen, eds. Proceedings of the 10th EURALEX International Congress. Copenhagen: Center for Sprogteknologi, 637-641.

Seznam ekscerpiranih del (1965). Ljubljana: Inštitut za slovenski jezik SAZU. Leksikološka sekcija. Shakespeare, William (1600/1905): Beneški trgovec [The Merchant of Venice]. (Translated by Oton Župančić) Poslovenil Oton Župančič. Ljubljana: Slovenska matica.

Shakespeare, William (1600/1921): Beneški trgovec [The Merchant of Venice]. (Translated by Oton Župančić) Poslovenil Oton Župančıč. Ljubljana: Nova založba.

Shakespeare, William (1600/1948): Beneški trgovec [The Merchant of Venice]. (Translated by Oton Župančić) Poslovenil Oton Župančič. In: Izbrano delo. Ljubljana: Državna založba Slovenije, 5-86.

Shakespeare, William (1600/1971): Beneški trgovec [The Merchant of Venice]. (Translated by Oton Župančić) Poslovenil Oton Župančič. In: Matej Bor, ed. William Shakespeare. Zbrana dela. Ljubljana: Državna založba Slovenije, 273-355.

Shakespeare, William (1600/1972): Beneški trgovec [The Merchant of Venice]. (Translated by Oton Župančić) Poslovenil Oton Župančič. Ljubljana: Mladinska knjiga.

Slovar slovenskega knjižnega jezika [Standard Slovenian Dictionary] (1970-1991). Ljubljana: SAZU, Inštitut za slovenski jezik, and Državna založba Slovenije.

Slovenski pravopis [Dictionary of the Slovenian Normative Guide] (2001). Ljubljana: SAZU and ZRC SAZU, Inštitut za slovenski jezik Frana Ramovša.

Sмiтн, Bruce R. (1994): Homosexual Desire in Shakespeare's England: A Cultural Poetics. Chicago: University of Chicago Press.

Sovrè, Anton (1939): Stari Grki. Celje: Družba sv. Mohorja.

Sovrè, Anton (1960): Uranizem pri Starih Grkih. In: Platon. Simposion in Gorgias. Ljubljana: Slovenska Matica, 7-22.

StANOvnik, Majda (2005): Slovenski literarni prevod 1550-2000. Ljubljana: Založba ZRC, ZRC SAZU.

Sumara, Dennis and Davis, Brent (1999): Interrupting Heteronormativity: Toward a Queer Curriculum Theory. Curriculum Inquiry. 29(2):191-208.

Thomas, George (1997): The Impact of Purism on the Development of the Slovene Standard Language. Slovenski jezik [Slovene Linguistic Studies]. 1(1):133-152.

Toury, Gideon (1995): The Nature and Role of Norms in Translation. In: Gideon Toury, ed. Descriptive Translation Studies and Beyond. Amsterdam/Philadelphia: John Benjamins, 53-69.

Yep, Gust A., LovaAs, Karen E. and EliA, John P., eds. (2003): Queer Theory and Communication: From Disciplining Queers to Queering the Discipline(s). New York: Harrington Park Press.

Zupan Sosič, Alojzija (2005): Homoerotika v novejšem slovenskem romanu. Jezik in slovstvo. 50(3-4): 5-16.

Zupančič, Mirko (1972): Spremna beseda. In: William Shakespeare. Beneški trgovec. Ljubljana: Mladinska knjiga, 90-99.

Župančič, Oton (1905): Tolmač. In: William Shakespeare. Beneški trgovec. Ljubljana: Slovenska matica, 117-119.

Župančič, Oton (1921): Opazke. In: William Shakespeare. Beneški trgovec. Ljubljana: Nova založba, 146-154. 